\title{
Statyba
}

\section{USABILITY OF LITHUANIAN FUSIBLE CLAY FOR SINTERED CERAMICS}

\section{R. Žurauskienè MSc. , R. Mačiulaitis \& F. Petrikaitis}

To cite this article: R. Žurauskienè MSc. , R. Mačiulaitis \& F. Petrikaitis (2001) USABILITY

OF LITHUANIAN FUSIBLE CLAY FOR SINTERED CERAMICS, Statyba, 7:3, 191-196, DOI:

10.1080/13921525.2001.10531723

To link to this article: https://doi.org/10.1080/13921525.2001.10531723

曲 Published online: 30 Jul 2012.

Submit your article to this journal $\pi$

Џ Article views: 76 


\title{
LIETUVOS TERITORIJOJE ESANČIŲ LENGVAI LYDŽIŲ MOLIŲ TINKAMUMAS STATYBINEI SUKEPUSIAJAI KERAMIKAI
}

\author{
R. Žurauskienè, R. Mačiulaitis, Vilniaus Gedimino technikos universitetas, \\ F. Petrikaitis, Termoizoliacijos institutas
}

\section{Ivadas}

Šiuo metu Lietuvoje gaminami keraminiai fasadiniai gaminiai yra higroskopiški ir neatsparūs drègnoms žiemoms, vyraujančioms mūsu šalies teritorijoje. Dalis keraminiu fasadiniu plytu, net ir atitinkančiı atsparumo šalčiui reikalavimus, pradeda irti pastaty eksploatavimo pradžioje [1].

Prailginti pastatų išorès apdailos ilgaamžiškumą galima naudojant sukepusiają statybinę keramiką, kuri igeria iki $5 \%$ vandens (LST 1458) ir pagal eksploatacini atsparumą šalčiui atitinka A.2. arba A.3. ilgaamžiškumo kategorijas (LST1428.19:1998).

Lietuvoje esantis molis yra lengvai lydus, o jo sukepimo intervalas gana siauras $\left(\leq 60^{\circ} \mathrm{C}\right)$. Jis naudojamas paprastu ir keraminiu apdailos plytu, blokų, čerpiu gamybai. Sukepusiosios keramikos ir klinkerinès plytos Lietuvoje negaminamos [2].

Literatūros duomenimis [3], iš vietiniụ lengvai besilydančių moliu su priedais galima gaminti statybinès sukepusiosios keramikos gaminius, tinkančius pastatu išorès apdailai. Šiu keraminių gaminiu vandens imirkis ne didesnis kaip 5\%, ju šukè yra tanki, stipri ir atspari šalčiui. Molio sukepimo intervalas gali būti praplèstas naudojant keliu molio telkiniu žaliavas, kuriu skirtinga granuliometrinè ir mineraloginè sudètis, arba naudojant priedus [3].

Buvo išnagrinètos visu Lietuvos didesnių radaviečiu molio sudetys, siekiant pasirinkti tinkamiausią žaliavą sukepusiosios keramikos gamybai. Naudota Vinklerio trifazè diagrama [4] ir Avgustiniko moliu grupavimas pagal ju cheminę sudeti [5].

Pagal šias diagramas Lietuvos moliai yra tinkami tik statybinèms plytoms, čerpèms ir plonasieniams dirbiniams gaminti. Be chemines ir granuliometrinès sudèties koregavimo né vienas molis netinka klinkeriniu plytu gamybai.
Darbo tikslas - gauti statybinę sukepusiają keramiką naudojant vietines žaliavas bei nebrangius atsivežtinius priedus, nustatyti, kokią itaką sunkiai lydžiu molių priedas turi sukepusiosios keramikos šukès fizikinems bei mechaninèms savybèms, jos atsparumui šalčiui. Taip pat ištirti, ar tikslinga i formavimo masę deti lauko špato ir perlito priedu, kurie yra naudojami sukepusiosios keramikos plonasieniams dirbiniams - apdailos plytelèms gaminti.

\section{Tyrimų metodikos ir žaliavos}

Bandinių tankis, stipris lenkiant ir gniuždant buvo nustatomi pagal LST 1272-92.

Bandinių vandens imirkis vakuumuojant nustatytas pagal specialią metodiką [1]. Remiantis ju imirkio (po $72 \mathrm{~h}$, po $72 \mathrm{~h}+5 \mathrm{~h}$ juos pavirinus, po vakuumavimo) rezultatais, apskaičiuoti: įsotinimo koeficientas, ịsotinimo koeficientas vakuumuojant ir rezerviniu porı kiekis [1].

Keraminiu bandiniu stiprio prognozavimas neardomuoju ultragarso impulso greičio nustatymo metodu remiasi ultragarso išilginių bangu impulso sklidimo greičio bandinyje nustatymo metodika. Naudotas impulso greičio nustatymo prietaisas UK-14 P (Rusija) (LST 1428.10:1996).

Tiriant bandiniu atsparumą šalčiui tūriniu šaldymo būdu, jie laikyti šaldymo kameroje su priverstine ventiliacija ir automatiškai reguliuojant temperatūra (LST 1272-92). Tiriant bandiniu atsparumą šalčiui vienpusio šaldymo ir atitirpinimo būdu jie laikyti šaldymo-lietinimo irenginyje (ChDU) (LST 1272-92).

Rentgenofaziniu tyrimu metodu atlikta išdegtu bandiniu fazinè analizè. Naudotas difraktometras DRON-2 (Rusija) su $\mathrm{Cu}$ antikatodu ir $\mathrm{Ni}$ filtru, kai $U=30 \mathrm{kV}, I_{a}=8 \mathrm{~mA}$ ir bandinio sukimo greitis $1^{\circ} \mathrm{min}^{-1}$. Rentgenogramos užregistruotos popieriuje savirašiu ir iššifruotos, palyginti su duomenimis PDC kartotekoje bei mokslinejje literatūroje [6]. 
1 lentelè. Molio ir kitų žaliavı cheminè sudètis

Table 1. Chemical compositions of the clay and other materials

\begin{tabular}{|c|c|c|c|c|c|c|c|c|c|c|c|}
\hline \multirow{2}{*}{ Žaliava } & \multicolumn{11}{|c|}{ Cheminè sudètis, \% } \\
\hline & $\mathrm{SiO}_{2}$ & $\mathrm{Al}_{2} \mathrm{O}_{3}$ & $\mathrm{Fe}_{2} \mathrm{O}_{3}$ & $\mathrm{CaO}$ & $\mathrm{MgO}$ & $\mathrm{K}_{2} \mathrm{O}$ & $\mathrm{Na}_{2} \mathrm{O}$ & $\mathrm{TiO}_{2}$ & $\mathrm{P}_{2} \mathrm{O}_{5}$ & $\mathrm{SO}_{3}$ & $\mathbf{K}^{*}$ \\
\hline Ukmergès molis & 66,33 & 15,8 & 6,42 & 1,8 & 2,72 & 1,63 & - & & - & - & 6,85 \\
\hline Roku molis & 47,22 & 18,33 & 7,1 & 7,14 & 3,84 & 0,14 & - & & - & - & 12,08 \\
\hline Nikiforovo molis & 56,02 & 23,43 & 9,17 & 0,75 & 0,74 & - & - & & - & 0,93 & 8,9 \\
\hline Vesiolovo molis & 53,23 & 31,32 & 1,49 & 1,03 & 1,42 & 1,21 & 0,55 & & - & - & 10,37 \\
\hline Lauko špatas & 69,78 & 18,42 & 0,13 & 0,64 & 0,19 & 0,19 & 9,7 & 0,32 & 0,29 & - & 0,34 \\
\hline Perlitas & 72,98 & 12,92 & 2,25 & 0,88 & - & 2,56 & 2 & - & - & - & 5,2 \\
\hline
\end{tabular}

* Kaitmenys $1000{ }^{\circ} \mathrm{C}$ temperatūroje

Bandiniụ linijinių matmenų kitimas degimo metu buvo nustatomas dilatometru DKV (Rusija), temperatūrų intervalu nuo $20^{\circ} \mathrm{C}$ iki $1100{ }^{\circ} \mathrm{C}$. Temperatūros kèlimo greitis $4{ }^{\circ} \mathrm{C} \mathrm{min}^{-1}$. Dujų terpe kaitinimo krosnelèje - oras. Tyrimams naudotas korundinis vamzdelis. Maksimalioje temperatūroje bandiniai išlaikyti iki $1 \mathrm{~h}$. Ilgio pokytis nustatytas indikatoriumi, kurio padalos vertè $0,001 \mathrm{~mm}$. Cilindrinès formos bandiniai iš modeliniu formavimo mišinių buvo presuojami išspaudimo būdu (preso galvutès skersmuo $10 \mathrm{~mm}$ ). Išdžiovinti bandiniai išdegti dilatometre.

Tyrimams buvo atrinkti Ukmergès ir Roku radaviečiu moliai. Panaudoti ir sunkiai lydūs moliai iš Vesiolovo ir Nikiforovo radaviečiu Ukrainoje. I formavimo masę i̇maišyti fliusuojantys priedai, žeminantys keraminès šukès susidarymo temperatūrą ir didinantys lydalo kieki, tokie kaip lauko špatas ir perlitas (Ukraina). Visų šių žaliavų cheminè sudètis pateikta 1 lenteléje. Moliụ granuliometrinè sudètis pateikta 2 lentelèje.

Darbe naudoti liesikliai - išdegtụ bandinių skaldelè ir "Centrolito“ liejykloje naudota formavimo žemè, kurią sudaro nuo $5,5 \%$ iki $6 \%$ tirpaus stiklo sujungtas kvarcinis smèlis. Jo granuliometrinè sudètis pateikta 3 lentelèje.

Smèlio stambumo modulis 1,3 , o molio ir dulkiu dalelių kiekis $5,6 \%$.

Ruošiant formavimo mišinius, visi komponentai prieš dozavimą buvo išdžiovinti nuo $100^{\circ} \mathrm{C}$ iki $110^{\circ} \mathrm{C}$ temperatūroje, sumalti ir išsijoti per $1 \mathrm{~mm}$ sietą. Išdegtų bandiniu skaldelè sijota per $2,5 \mathrm{~mm}$ sieta.

Fizikinèms bei mechaninèms savybèms ir atsparumui šalčiui nustatyti plastiniu formavimo būdu buvo su-
2 lentelè. Svarbiausių molių granuliometrinè sudètis

Table 2. Grading of the main clays

\begin{tabular}{|l|c|c|}
\hline \multirow{2}{*}{ Frakciju dydis, mm } & \multicolumn{2}{|c|}{ Daleliụ kiekis, \% } \\
\cline { 2 - 3 } & Ukmergès molis & Rokų molis \\
\hline Smélio dalelių $>0,05$ & $13,26-35.66$ & $0,09-0,77$ \\
\hline Dulkių dalelių 0,05-0,005 & $22,71-33,49$ & $9,26-21,39$ \\
\hline Molio dalelių <0,005 & $33,68-58,28$ & $72,11-96,04$ \\
\hline
\end{tabular}

3 lentelè. Smèlio granuliometrinè sudètis

Table 3. Grading of the sand

\begin{tabular}{|c|c|c|}
\hline \multirow{2}{*}{ Sieto Nr. } & \multicolumn{2}{|c|}{ Likutis, \% } \\
\cline { 2 - 3 } & dalinis likutis & visas likutis \\
\hline 2,5 & 0,02 & 0,02 \\
\hline 1,25 & 0,298 & 0,318 \\
\hline 0,63 & 3,53 & 3,85 \\
\hline 0,5 & 3,52 & 7,37 \\
\hline 0,315 & 32,36 & 39,73 \\
\hline 0,14 & 39,96 & 79,69 \\
\hline$<0,14$ & 20,3 & 100 \\
\hline
\end{tabular}

formuoti bandiniai iš 4 lenteleje pateiktų formavimo mišinių.

Paruošti bandiniai pirmiausia natūraliai išdžiovinti laboratorijoje, vèliau tris paras džiovinti elektrinèje džiovykloje, palaikant nuo $100{ }^{\circ} \mathrm{C}$ iki $110^{\circ} \mathrm{C}$ temperatūra. Išdžiovinti bandiniai išdegti elektrinèje mufelinèje krosnyje su automatiniu temperatūros reguliatoriumi TY-204 (Rusija) ( $1{ }^{\circ} \mathrm{C}$ tikslumu). Aukščiausia bandiniu degimo temperatūra $1070{ }^{\circ} \mathrm{C}$, ji atitinka vidutinę vietiniu molių sukepimo temperatūrą. Degimo trukmè $40 \mathrm{~h}$, aukščiausioje degimo temperatūroje išlaikyta $7 \mathrm{~h}$. 
4 lentelè. Formavimo mišiniu sudètys

Table 4. Composition of forming mixtures

\begin{tabular}{|c|l|}
\hline $\begin{array}{c}\text { Eil. } \\
\mathrm{Nr} .\end{array}$ & \multicolumn{1}{|c|}{$\begin{array}{c}\text { Formavimo mišinių sudetys; medžiagų kiekiai, } \\
\% \text { (masès) }\end{array}$} \\
\hline 1 & $\mathrm{R}^{*} 37, \mathrm{~N}^{*} 15, \mathrm{~V}^{*} 15, \mathrm{~L}^{*} 4, \mathrm{P}^{*} 4, \mathrm{C}^{*} 17, \mathrm{~S}^{*} 8$ \\
\hline 2 & $\mathrm{R}^{*} 43, \mathrm{~N}^{*} 15, \mathrm{~V}^{*} 15, \mathrm{C}^{*} 17, \mathrm{~S}^{*} 10$ \\
\hline 3 & $\mathrm{R}^{*} 39, \mathrm{~N}^{*} 15, \mathrm{~V}^{*} 15, \mathrm{P}^{*} 4, \mathrm{C}^{*} 17, \mathrm{~S}^{*} 10$ \\
\hline 4 & $\mathrm{R}^{*} 39, \mathrm{~N}^{*} 15, \mathrm{~V}^{*} 15, \mathrm{~L}^{*} 4, \mathrm{C}^{*} 17, \mathrm{~S}^{*} 10$ \\
\hline 5 & $\mathrm{R}^{*} 55, \mathrm{~N}^{*} 20, \mathrm{C}^{*} 17, \mathrm{~S}^{*} 8$ \\
\hline 6 & $\mathrm{R}^{*} 55, \mathrm{~V}^{*} 20, \mathrm{C}^{*} 17, \mathrm{~S}^{*} 8$ \\
\hline 7 & $\mathrm{R}^{*} 44, \mathrm{~N}^{*} 15, \mathrm{~V}^{*} 15, \mathrm{~L}^{*} 8, \mathrm{P}^{*} 8, \mathrm{~S}^{*} 10$ \\
\hline 8 & $\mathrm{R}^{*} 20, \mathrm{U}^{*} 80$ \\
\hline 9 & $\mathrm{R}^{*} 40, \mathrm{U}^{*} 60$ \\
\hline 10 & $\mathrm{U}^{*} 70, \mathrm{~N}^{*} 30$ \\
\hline 11 & $\mathrm{R}^{*} 32, \mathrm{U}^{*} 40, \mathrm{~N}^{*} 20$ \\
\hline
\end{tabular}

* R - Rokų molis, U - Ukmergès molis, N - Nikiforovo molis, V - Vesiolovo molis, L - lauko špatas, $\mathrm{P}$ - perlitas, C - „Centrolito" smèlis, S - išdegtu bandinių skaldelè.

\section{Darbo rezultatai ir jų aptarimas}

Skirtingos sudeties bandinių fizikiniu bei mechaninių savybių ir atsparumo šalčiui rodikliai pateikti 5 lentelèje. Tarp šiu rodiklių yra koreliacinis ryšys: mažèjant keraminès šukès vandens imirkiui, dideja jos tankis, degamasis susitraukimas, rezervinių poru skaičius, stipris gniuždant, ultragarso impulso sklidimo greitis.

Iš šiame darbe nagrinejamų formavimo mišinių labiausiai sukepusi keraminè šukè gaunama, kai bandinių sudettis Nr. 8 ir Nr. 10 (4 lent.). Šiu bandinių vandens imirkis po $72 \mathrm{~h}$ svyruoja apie $2 \%$ (5 lent.). Per pirmasias 7 mirkymo valandas jie igère tik apie $1 \%$ vandens, todèl remiantis [7] galima prognozuoti, kad ju atsparumas šalčiui bus didelis.

Bandiniu Nr. 7-11 tankis yra didesnis kaip $2000 \mathrm{~kg} / \mathrm{m}^{3}$, ju bendrasis susitraukimas nuo $10,14 \%$ iki $11,04 \%$. Bandiniy Nr. 1-6 tankis nesiekia $2000 \mathrm{~kg} / \mathrm{m}^{3}$, ju ir susitraukimas mažesnis.

Šaldant bandinius vienpusio šaldymo ir atšildymo būdu, bandiniuose Nr. 2, 3, 7-11 po 75 šaldymo ir atitirpinimo ciklu suirimo žymių neaptikta. Todèl tokie keraminiai bandiniai jau atitinka A.2. ilgaamžiškumo kategoriją (LST 1428.19:1998).

Bandiniai Nr. 8-11, šaldomi tūriniu šaldymo ir atšildymo būdu (5 lent.), po 180 ciklu (Nr. 9 - 260 ciklu) nesuiro ir buvo šaldomi toliau. Be to, kaip matyti iš 5 lentelès duomenų, šie bandiniai turi didžiausią rezerviniu poru skaičiu (nuo $55 \%$ iki $73 \%$ ), ju imirkis po $72 \mathrm{~h}$ yra mažesnis nei 5\%, stipris gniuždant $17-28 \mathrm{MPa}$. Lengvai užsipildančios šaltu vandeniu poros apibūdina keraminès medžiagos efektyvuji poringuma, kuris apskaičiuojamas pagal vandens imirki po 72 h [7]. Tiksliau bendrasis atvirasis poringumas išreiškiamas vandens igèrimu vakuume, t. y. kai oras iš poru ir kapiliaru pašalinamas gana intensyviai. Rezervinių poru skaičius priklauso nuo bandinių imirkio po $72 \mathrm{~h}$ ir jų imirkio po vakuumavimo.

Nors keraminiu bandinių stiprio prognozavimas ultragarso impulso greičio nustatymo metodu nèra labai

5 lentelè. Laboratorinių bandinių fizikinès bei mechaninès savybès

Table 5. Physical-mechanical properties of laboratory samples

\begin{tabular}{|c|c|c|c|c|c|c|c|c|c|c|c|c|}
\hline $\begin{array}{l}\text { Eil } \\
\mathrm{Nr} .\end{array}$ & $\begin{array}{c}\text { Džūīstamasis } \\
\text { susitrau- } \\
\text { kimas, \% }\end{array}$ & $\begin{array}{c}\text { Bendrasis } \\
\text { susitrauki- } \\
\text { mas, } \%\end{array}$ & $\begin{array}{l}\text { Tan- } \\
\text { kis, } \\
\mathrm{kg} / \mathrm{m}^{3}\end{array}$ & $\begin{array}{c}\text { Imirkis } \\
\text { po } 72 \mathrm{~h} \text {, } \\
\%\end{array}$ & $\begin{array}{l}\text { Isotinimo } \\
\text { koefi- } \\
\text { cientas } K_{\text {is }}\end{array}$ & $\begin{array}{l}\text { Imirkis po } \\
\text { vakuuma- } \\
\text { vimo, \% }\end{array}$ & $\begin{array}{c}\text { Isotinimo koefi- } \\
\text { cientas po vakuu- } \\
\text { mavimo } \mathrm{K}_{\text {is vak }}\end{array}$ & $\begin{array}{c}\text { Rezervi- } \\
\text { niu pony } \\
\text { skaičius, } \\
\%\end{array}$ & $\begin{array}{l}\text { Stipris } \\
\text { gniuž- } \\
\text { dant, } \\
\mathrm{MPa}\end{array}$ & $\begin{array}{l}\text { Stipris } \\
\text { lenkiant, } \\
\text { MPa }\end{array}$ & $\begin{array}{l}\text { Ultragarso } \\
\text { impulso } \\
\text { greitis, } \mathrm{m} / \mathrm{s}\end{array}$ & $\begin{array}{l}\text { Atspa- } \\
\text { rumas } \\
\text { šalčiui, } \\
\text { ciklais }\end{array}$ \\
\hline 1 & 5,63 & 9,63 & 1907 & 9,39 & 0,72 & 13,95 & 0,72 & 32,6 & 18,11 & 7,72 & 2638 & 92 \\
\hline 2 & 5,78 & 10,54 & 1905 & 8,57 & 0,71 & 13,06 & 0,68 & 34,4 & 19.44 & 8,07 & 2805 & 130 \\
\hline 3 & 5,12 & 9,22 & 1922 & 9,22 & 0,74 & 12.98 & 0,71 & 29.0 & 17,37 & 8,23 & 3034 & 194 \\
\hline 4 & 4,99 & 8,73 & 1916 & 9,01 & 0,70 & 13,08 & 0,69 & 31,1 & 14,95 & 7,23 & 2965 & 170 \\
\hline 5 & 5,54 & 8,54 & 1913 & 9,79 & 0,77 & 13,58 & 0,75 & 27,9 & 16,6 & 7,91 & 2991 & 76 \\
\hline 6 & 5,24 & 9,94 & 1931 & 7,97 & 0,68 & 11,84 & 0,67 & 32,7 & 14,18 & 8,66 & 3201 & 89 \\
\hline 7 & 5,20 & 10,90 & 2009 & 5,93 & 0,68 & 9,41 & 0,62 & 37,6 & 17,91 & 13,63 & 3740 & 126 \\
\hline 8 & 6,18 & 10,78 & 2175 & 2,16 & 0,87 & 6,89 & 0,31 & 68,7 & 28,03 & 11,84 & 3911 & $180^{*}$ \\
\hline 9 & 6,10 & 11,04 & 2085 & 1,97 & 0,83 & 7,40 & 0,27 & 73,4 & 27,63 & 13,99 & 4075 & $260^{*}$ \\
\hline 10 & 5,50 & 10,68 & 2247 & 2,27 & 0,82 & 5,94 & 0,38 & 61,6 & 27,75 & 13,40 & 4116 & $180^{*}$ \\
\hline 11 & 5,90 & 10,14 & 2115 & 3,24 & 0,73 & 7,25 & 0.44 & 55,7 & 17,32 & 12,28 & 3902 & $180^{*}$ \\
\hline
\end{tabular}

* Šie bandiniai nesuirę, jie buvo šaldomi toliau. 
tikslus dèl keraminių bandinių stiprumo rodiklių lokaliniu svyravimu, tačiau, kaip matyti iš 5 lentelès duomenų, bandinių kuriụ Nr. 8-11, ultragarso impulso sklidimo greitis kaip ir stipris gniuždant yra didesni nei kitu bandinių.

Sukepimo intervalui praplèsti i lengvai lydžius molius dedama nuo $10 \%$ iki $30 \%$ sunkiai lydžiu moliu [8], tačiau tokio molio naudojimas (Nr. 10, 5 lent.) neturi labai didelès itakos sukepusiosios statybinès keramikos savybèms. Panašūs rezultatai gaunami i Ukmergès moli imaišius kitokios granuliometrinès sudèties Roku molio.

Bandiniu Nr. 5, 6 ir Nr. 10 fizikinių bei mechaniniu charakteristiku reikšmès labai skiriasi. Pirmieji bandiniai (4 lent.) buvo pagaminti iš formavimo masès, kurios sudetyje yra 55\% Roku molio ir 20\% sunkiai lydaus molio, o bandinio Nr. 10 formavimo mišinyje $70 \%$ Ukmergès molio ir 30\% sunkiai lydaus molio. Ukmergès molis pagal anksčiau nagrinètas diagramas labiau tinka sukepusiosios keramikos gamybai. Šio bandinio savybès atitinka reikalavimus, keliamus sukepusiajai keraminei šukei.

Fliusuojantys priedai, dedami i formavimo masę, nepagerino keraminès šukès fizikiniu bei mechaninių savybių. Didžiausias šių priedu kiekis pridètas $\mathfrak{i}$ formavimo mase Nr. 7 - 16\% (1:1 lauko špatu:perlito) (1 pav.). Pagal literatūrą [8] fliusuojančiu priedu kiekis turètu būti nuo $20 \%$ iki $30 \%$ (naudojant po vieną arba kompleksiškai santykiu $1: 2 ; 1: 1$ arba $2: 1$ ), tačiau tai labai pabrangintu gaminamas plytas.

Visu laboratorinių bandinių dilatometrinès kreivès būdingos karbonatiniams moliams. 1 paveiksle pateiktos formavimo mišinio Nr. 8 dilatometrinè ir diferencinè kreivès. Kaitinant bandinèli pastebimas jo išsiplètimas iki $0,4 \%$ ( 1 a pav.). Vyrauja du pagrindiniai susitraukimo etapai. Kaitinant bandini iki $1080{ }^{\circ} \mathrm{C}$ temperatūros jis susitraukè $3,5 \%$, o bendras susitraukimas $1 \mathrm{~h}$ išlaikius $1080{ }^{\circ} \mathrm{C}$ temperatūroje siekè $6,5 \%$. Iš diferencinès kreivès ( 1 b pav.) matyti, kad didžiausią reikšmę bandinio išsiplètimo greitis pasiekia $540{ }^{\circ} \mathrm{C}$ temperatūroje. $820^{\circ} \mathrm{C}$ temperatūroje prasideda susitraukimo procesas, kuris absoliutu minimumą pasiekia esant $860^{\circ} \mathrm{C}$. Antrojo susitraukimo etapo pradžia $940^{\circ} \mathrm{C}$, o minimali reikšmè pasiekta esant $1040^{\circ} \mathrm{C}$.

Bandinio terminio išsiplètimo intensyvumo padidèjimas $550^{\circ} \mathrm{C}$ temperatūroje priklauso nuo molio, mine-
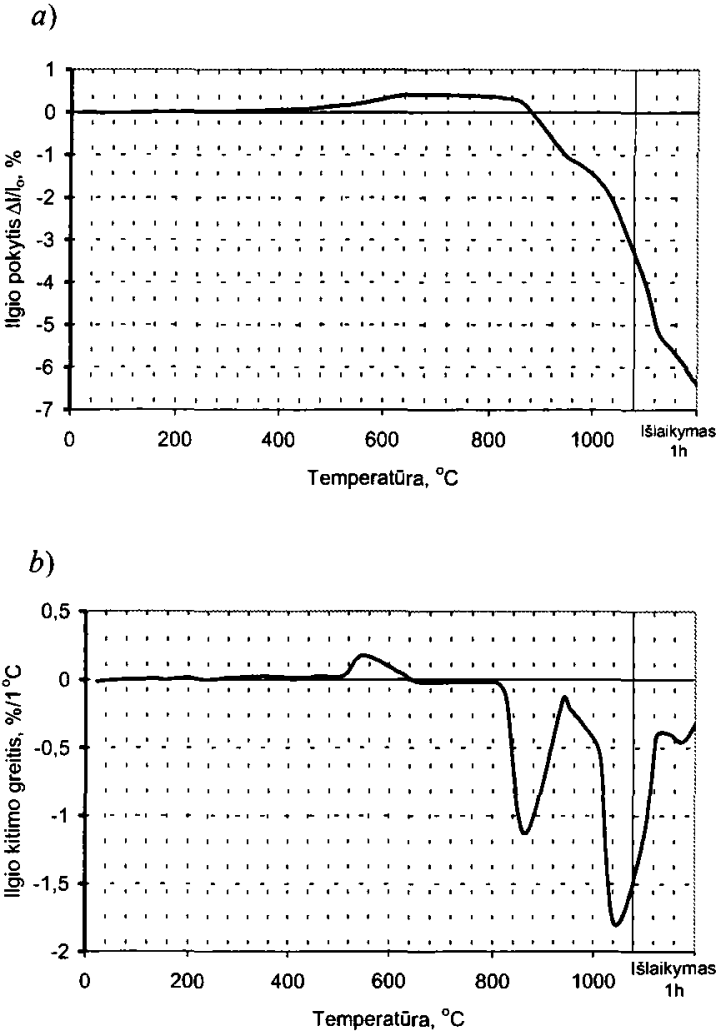

1 pav. Bandinio Nr. 8 dilatometrinè - $a$ ir diferencinè $b$ kreivès

Fig 1. Dilatometric $a$ and differential $b$ curves of examples No 8

ralinèje struktūroje esančio $\mathrm{OH}$, išsidèsčiusio tarp $\mathrm{Si}$ tetraedro sluoksnių, kuris šioje temperatūroje išsiskiria vandens pavidalu, padidina slègi ir virsdamas metakaolinu padidina atstumą tarp tetraedro sluoksnių [9]. Intensyviausiai bandinio susitraukimas vyksta nuo $860^{\circ} \mathrm{C}$ iki $940^{\circ} \mathrm{C}$ ir nuo $1000^{\circ} \mathrm{C}$ iki $1070^{\circ} \mathrm{C}$ temperatūrose, aktyvusis $\mathrm{CaO}$ reaguoja su dehidratuotais moliais ir vyksta naujadaru kristalizacija. Visuose formavimo mišiniuose susitraukimo pradžios temperatūra yra $800^{\circ} \mathrm{C}$. Tokie procesai greičiausiai yra susiję su karbonatu skilimu, jie būdingi visiems karbonatiniams moliams [10].

Iš bandinio Nr. 8 rentgenografinès analizès (2 pav. A - anortitas, Q - kvarcas, Šp - špinelis) matyti, kad jame po išdegimo susidaro anortitas, intensyviausios smailes yra: 0,$404 ; 0,377 ; 0,345 ; 0,326 ; 0,323 ; 0,320$; 0,177 (hm).

Išdegus gryną Ukmergès moli $1000^{\circ} \mathrm{C}$ temperatūroje [11] (išlaikyta $1 \mathrm{~h}$ ) rentgenogramoje yra trys anortito smailès: $0,322,0,373,0,404(\eta \mathrm{m}) .0,322 \mathrm{hm}$ smailè yra mažesnio intensyvumo. 


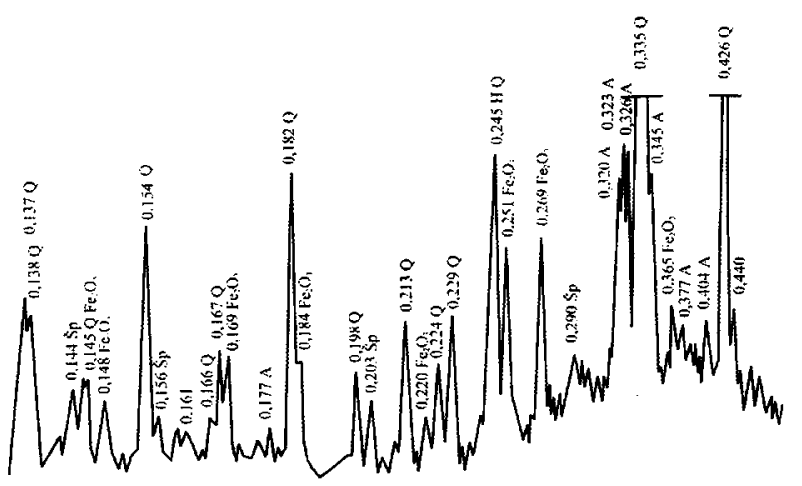

2 pav. Keraminès šukès Nr. 8 rentgenograma (nm)

Fig 2. XRD pattern $(\mathrm{nm})$ of ceramic splinter No 8

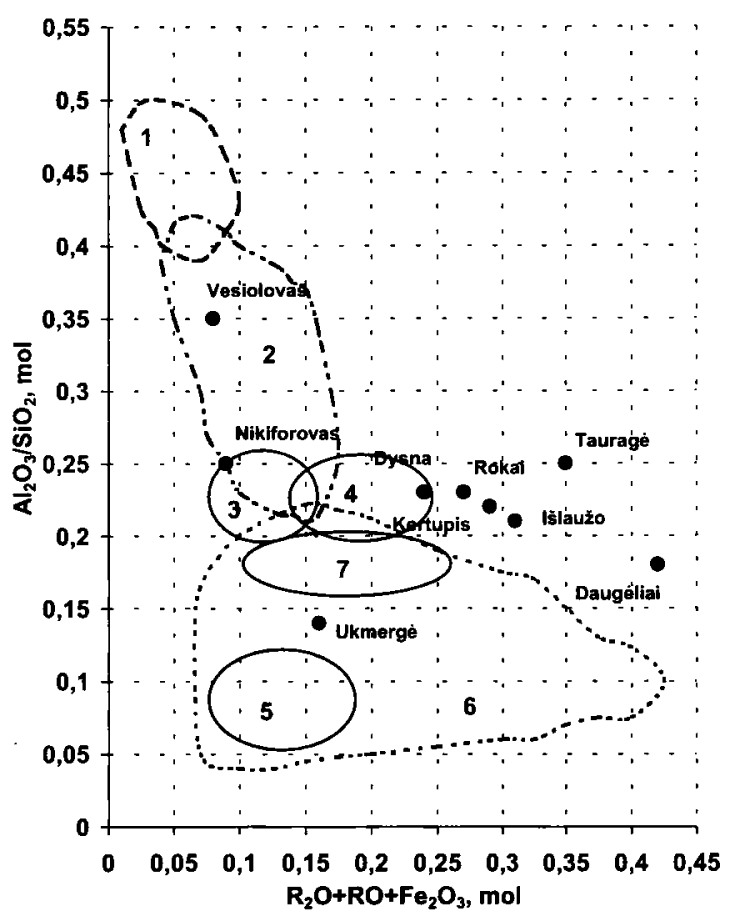

3 pav. Moliu grupavimas pagal jų funkcinę cheminę sudèti: 1 - ugniai atspariems gaminiams; 2 - grindu plytelèms, kanalizacijos vamzdžiams; 3 - žiedimo molis; 4 čerpiu molis; 5 - klinkerinis molis; 6 - plytu molis; 7 išskirtoji bandymu metu sukepusiosios keramikos sritis

Fig 3. Grouping of the clay by functional chemical composition: 1 - refractory products; 2 - ceramic floor tiles, sewerage pipes; 3 - potters craft; 4 - roof tiles; 5 clinker bricks; 6 - ceramic bricks; 7 - in experiments separated sintered ceramics

Šiuo metu Lietuvoje naudojamų molio telkiniu tinkamumas tam tikru gaminiu gamybai parodytas 3 paveiksle. 1-6 sritis pateikta pagal Avgustiniko diagramą [5], 7-oji sritis išskirta remiantis atliktais tyrimais. Naudojant molio mišinius, pagal granuliometrinę sudetị ieinančius $\mathfrak{i}$ šią sritị, gauta sukepusioji statybinè kerami- ka, kurios imirkis iki 5\%, tankis didesnis kaip $2000 \mathrm{~kg} / \mathrm{m}^{3}$, stipris gniuždant apie $27 \mathrm{MPa}$. Tačiau iš šios srities mišinil pagaminti sukepusiosios keramikos bandiniai neatitinka klinkerinems plytoms keliamų stiprio gniuždant reikalavimu.

\section{Išvados}

1. Iš vietinių lengvai lydžių moliu su priedais galima gauti efektyvią statybinę sukepusiają keramika, tinkančią pastatų išorès apdailai.

2. Iš visu bandinių, kurių formavimo mišinio sudètys pateiktos 4 lentelëje, reikalavimus, keliamus sukepusiajai keraminei šukei labiausiai atitinka Nr. 8 mišinys. Šie bandiniai suformuoti iš Ukmergès ir Rokų radaviečiu moliu mišinio santykiu $4: 1$. Ju vandens imirkis gerokai mažesnis nei $5 \%$, vidutinis tankis apie $2200 \mathrm{~kg} / \mathrm{m}^{3}$, stipris gniuždant $28 \mathrm{MPa}$, stipris lenkiant $11,8 \mathrm{MPa}$, atsparumas šalčiui vienpusio šaldymo metodu daugiau nei 75 ciklai.

3. Ukmergès moli maišant su sunkiai lydžiu Nikiforovo moliu (Ukmergès - 70\%, Nikiforovo - 30\%) gaunami keraminès šukès fizikiniu bei mechaniniu savybiu rodikliai, atitinkantys sukepusiajai keraminei šukei keliamus reikalavimus. Tokių bandinių ilgaamžiškumas yra A.2. kategorijos (LST 1428.19:1998).

4. Fliusuojančiu priedu kiekis (nuo $8 \%$ iki $16 \%$ ) yra nepakankamas tam, kad gautume sukepusiajja šalčiui atsparią keraminę šukę.

\section{Literatūra}

1. R. Mačiulaitis. Fasadinès keramikos atsparumas šalčiui ir ilgaamžiškumas. Vilnius: Technika, 1996. 132 p.

2. A. Kaminskas. Statybinès medžiagos. Vilnius: VPU leidykla, 2000. 171 p.

3. Г. П. Седмале, У. Я. Седмалис. Спекшиеся керамические материалы из гидрослюдистых глин // Стекло и керамика, № 1, 2000, с. 25-27.

4. Trajan Ispas. Romania. The situation of the ceramic brick and roofing tile industry // Ziegelindustry International, No 9, 1995, p. 604-613.

5. А. И. Августиник. Керамика. Л.: Стройиздат, 1973. $532 \mathrm{c}$.

6. Hanawalt Search Manual. Inorganic Phases. Sets 1-48. Pensylvania: JCPDS, 1998. 600 p.

7. Р. Мачюлайтис. Морозостойкость и долговечность изделий фасадной керамики. Вильнюс: Техника, 1997. 307 с.

8. И. А. Левицкий, С. А. Гайлевич, Е. М. Дятлова. Плитки для полов на основе полиминеральных глин 
республики Беларусь // Стекло и керамика, № 11, 1995, c. $15-19$

9. I. Horvath, J. G. Fedorenko, J. G. Kukovskij. Vysokoteplotna dehydratacia kaolinitov // Silikaty, č. 4, 1986 , s. 311-318.

10. М. К. Кулбеков, Ш. И. Хамраев. Расчет термомеханических процессов при обжиге керамических материалов // Стекло и керамика, № 11, 1995, с. 26-27.

11. A. Sveikauskaitè. Kvarteriniuose ir devoniniuose aliumosilikatuose vykstančių reakcijų intensyvinimo tyrimas: Daktaro disertacija. Vilnius, 1997. $117 \mathrm{p}$.

Iteikta $200102 \quad 15$

\section{USABILITY OF LITHUANIAN FUSIBLE CLAY FOR SINTERED CERAMICS}

\section{R. Žurauskienė, R. Mačiulaitis, F. Petrikaitis}

S u m mary

Facade articles of ceramics being produced recently in Lithuania are hygroscopic and are not resistant to humid winters predominant in territory of our country. It is possible to prolong longevity of the exterior finishing of buildings by using sintered building ceramic which absorbs up to $5 \%$ moisture (LST 1458) and according to service frost resistance conforms to A.2. and A.3. categories of durability (LST 1428.19:1998).

The clay available in Lithuania is fusible, sintering interval of the clay is quite narrow $\left(\leq 60^{\circ} \mathrm{C}\right)$. It is used for production of common and finishing bricks, blocks, roof tiles. Bricks of sintered ceramic and clinker are not produced in Lithuania.

The aim of the work was to obtain sintered ceramics by using local raw materials together with not expensive imported additives.

For the research clay of Ukmerge deposits was selected according to three-phase diagram of Vinkler [4] and Avgustinik's classification [5] of chemical functional composition (Fig 3) and clay from Rokai deposit having different granulometric composition.

High-melting clays from Vesiolov's and Nikiforov's deposits in Ukraine were used in the work (Table 1). Feldspar and pearlite from Ukraine (Table 1) as flux additives were added into forming mass to achieve lower ceramic body formation temperature and to increase amount of melt mass.

Non-plastic materials used in the work are: crushed brick and waste moulding sand from "Centrolitas" foundry, which includes $5,5-6 \%$ of quartz sand binded by liquid glass. Grading of the sand is presented in Table 3.

Forming mixtures, composition of which is given in Table 4, were prepared.

Maximum temperature for batching of samples is $1070^{\circ} \mathrm{C}$, the temperature corresponds with average sintering temperature of local clays; burning time is 40 hours with exposure of 7 hours to maximum backing temperature.

The most sintered ceramic body was obtained in sam- ples No 8-11 out of all moulding mixtures used in the work (Table 5). The samples had water absorption content of $2-3 \%$.

At frost resistance test (by one side freezing) samples No 2, 3, 7-11 was without any signs of break-up after 75 cycles. These samples correspond to category A.2. of longevity (according to LST 1428.19:1998).

The samples No $8-11$ are being tested by volume freezing thawing achieved 180 cycles without any break-up (No $9-260$ cycles) and they are still under the test. The samples has the highest amount of reserved pores $(55-73 \%)$, compression strength is $17-28 \mathrm{MPa}$, bending strength is 12 $14 \mathrm{MPa}$.

Physical-mechanical properties of specimens No 5,6 and No 10 differs significantly. First specimens were produced out of forming mass, the composition of which consisted of $55 \%$ Rokai clay and $20 \%$ of high-melting clay, and forming mass composition of specimen No 10 consisted of $70 \%$ of Ukmergè clay and $30 \%$ of high-melting clay. Clay from Ukmerge is more suitable for production of sintered ceramics according to the diagrams examined above. Properties of this specimen conforms to requirements applied for sintered ceramic shiver.

Addition of flux additives into forming mass did not improve physical-mechanical properties of ceramic shiver. The highest amount $(16 \%)$ of the additive was added into forming mass No 7. Flux additives should comprise up to $20-30 \%$ of forming mass [8], but in this case price of such bricks would be increased significantly.

The main conclusion:

1. It is possible to obtain sintered building ceramics out of low-melting clays with additives suitable for exterior finishing of buildings.

Ramuné ŽURAUSKIENĖ. MSc. Doctoral student (since 1996), Vilnius Gediminas Technical University (VGTU), Saulètekio al. 11, LT-2040 Vilnius, Lithuania.

E-mail: kamiles@takas.lt

MSc (civil engineering, VTU, 1996). First degree in Civil Engineering (VTU, 1994). Research interests: materials science, technology of building ceramics from local raw materials, sintered ceramics.

Romualdas MAČIULAITIS. Doctor Habil, Professor. Head of Department of Building Materials. Vilnius Gediminas Technical University (VGTU), Sauletekio al. 11, LT-2040 Vilnius, Lithuania. E-mail: romac@takas.lt

A graduate of Vilnius University (1972). Doctor (technical sciences, 1980). Doctor Habil (technical sciences, 1993). Professor (1999). Author of more then 120 publications. Research interests: durability, frost resistance and other properties of building materials and products, fire prevention.

Fabijonas PETRIKAITIS. Doctor, Senior Researcher. Institute "Termoizoliacija", Linkmenu g. 28, LT-2600 Vilnius, Lithuania. E-mail: termo@aiva.lt

A graduate of KTU (1967). Doctor (technical sciences 1999). Author of about 50 scientific publications. Research interests: durability and production technology of building ceramics. 